\title{
Ischaemic myelopathy following aortic surgery or traumatic laceration of the aorta
}

\author{
JF Mathé ${ }^{1}$, I Richard ${ }^{1}$, JC Roger ${ }^{1}$, C Potagas $^{2}$, W S El Masry ${ }^{3}$ and B Perrouin-Verbe ${ }^{1}$ \\ ${ }^{1}$ Department of Physical Medicine \& Rehabilitation, Hopital St Jacques, CHRU de Nantes, 44035 Nantes, France; \\ ${ }^{2}$ Neurological Consultation General Hospital, Athens, Greece; ${ }^{3}$ Midlands Spinal Injuries Center, Oswestry, UK
}

\begin{abstract}
Paraplegia is one of the major complications following repair of aortic aneurysms or congenital malformations and from trauma of the aorta. In a series of 12 surviving patients we describe the clinical features as well as the evolution and pathophysiology of ischaemic lesions of the spinal cord. The clinical characteristics: loss of tendon reflexes, preservation of light touch sensation and bladder function, and the special topography of pin prick impairment, suggest involvement of the central grey matter. This lesion of the grey matter is incomplete in most of the patients and tends to extend for 2-10 segments. In some cases it can extend downward to the conus resulting in complete flaccid paraplegia. On follow-up we have observed limited improvement in most cases. No patient has recovered fully. Except in cases of traumatic laceration, where symptoms existed before surgery, paraplegia followed surgical repair in all other cases. Ischaemia can be related to the duration and the site of crossclamping of the aorta. Clamping above the left subclavian artery and/or a ligation of the intercostal arteries without previous visualisation of the spinal cord arteries can be dangerous. Other factors such as the phenomena of revascularisation and the presence of free radicals are discussed. These could explain delayed postischaemic spinal cord hypoperfusion.
\end{abstract}

Keywords: ischaemic myelopathy; aortic aneurysm complications; aortic laceration; aortic surgery complications

\section{Introduction}

Ischaemic myelopathy with paraplegia is one of the most serious and unpredictable complications following surgery or traumatic lesions of the aorta that those who manage such SCI patients are required to deal with. Unfortunately it is difficult to predict which patient will become paralysed. Doppman ${ }^{1}$ pointed out such a condition as the 'russian roulette for the vascular surgeon'. In recent studies, the incidence of post operative paraplegia was documented as $10 \%$ $50)$ by Schepens et $a l^{2}, 21 \%(25 / 116)$ by Cox et $a l^{3}$ and $13 \%(144 / 1062)$ by Crawford et al. ${ }^{4}$ Crawford in a randomized series, found that neurological deficits, of varying intensity and duration, affecting the lower extremities, occurred in 31 of 98 patients $(32 \%)$ with thoracoabdominal aneurysms of type I and II. In these cases cross-clamping is proximal to the left subclavian artery. The deficit was severe, in $21(68 \%)$ and mild in $10(32 \%)$ of the patients. In 21 patients the deficit was found immediately at the time of recovery from anaesthesia. In 10 patients there was a delay of several days before the paralysis occurred. In ischaemic myelopathy it is not always easy to clinically locate the lesion in the spinal cord and the involvement of the grey matter. Recent research of spinal cord blood flow

Correspondence: Professor JF Mathé and altered mechanisms of regulation can benefit our understanding of the pathophysiology of cord lesions in general.

\section{Materials and methods}

We report on twelve consecutive patients with spinal cord lesions, which occurred following aortic surgery for a congenital malformation or for repair of aneurysms or after an aortic laceration. Ten patients were examined between 1 day and 1 month from the onset and were subsequently followed up in our spinal cord unit. In two patients, the first examination was carried at 8 years (Case 1), and 5 years (Case 4) respectively. They were followed up at regular intervals thereafter. All patients are still alive.

The clinical assessment includes the documentation of the aortic lesion, the level of the spinal cord involvement, the ASIA score, when possible, the bladder status, the Frankel grading, the spread and extent of intra cord lesion and the neurological course. Special attention was given to the documentation of the site of the laceration or cross-clamping and its duration as well as the ligation of the intercostal arteries. Magnetic resonance imaging (MRI) was carried out in four patients and spinal cord angiography was carried out in one patient. 


\section{Results}

Table 1 summarizes the type of the aortic lesion, the surgical procedure and the preoperative neurological state. Three patients displayed traumatic laceration of the arch of the aorta $(1,5,10)$. Of these two had a preoperative paraplegia and one was neurologically unimpaired. Six had dissecting aortic aneurysms (3, 7, $8,9,11,12)$. All but one were neurologically unimpaired before the surgery. One patient had intermittent claudication (case 11). The six patients became paralysed after surgery. Three had cross-clamping above the left subclavian artery together with various number of intercostal arteries ligation. The remaining three patients (cases 2, 4, 6) had a congenital malformation of the aorta and were neurologically intact prior to surgery. The surgical records were available for two of the three patients. Two had clamping of the aorta above the left subclavian artery as well as intercostal arteries ligations. The duration of cross-clamping ranged between $55 \mathrm{~min}$ to $8 \mathrm{~h}$.
Regarding the neurological symptoms, little information is available concerning the exact time of onset of the diagnosis of paraplegia. Except in cases 1 and 10, where the paraplegia occurred soon after the trauma and before surgery, it was not easy to determine if the lesion had occurred during the surgical procedure or if it was delayed, as is often described in the literature.

Table 2 shows the main clinical features related to the ischaemia of the spinal cord at the first examination and their evolution during the followup. The ASIA Score could not be assessed in case 6, 1 year old patient, and in case 10 on account of an associated right brachial plexus lesion. An appreciation of the Frankel grade was often difficult regarding such lesions and served more as an indicator of the functional state than of a real sub-lesional state. Two patients (cases 1 and 2) presented with complete flaccid neurological impairment. In both, the flaccidity remained throughout their follow-up. For the ten remaining patients, (cases 3-12), there was only a

Table 1 Civil status, type of lesion, operative procedures

\begin{tabular}{|c|c|c|c|c|c|}
\hline No. & Sex & $D o B$ & $D o L$ & Type of Lesion & Operative procedure \\
\hline 1 & $\mathrm{~F}$ & 1940 & 1971 & $\begin{array}{l}\text { Traumatic laceration of the aortic arch, } \\
\text { with preoperative paraplegia Frankel A }\end{array}$ & Suture of the lesion \\
\hline 2 & M & 1991 & 1991 & $\begin{array}{l}\text { Ventricular septal defect, Ductus arteriosus } \\
\text { preoperative neurology normal }\end{array}$ & $\begin{array}{l}\text { Aortic ligation above left subclavian } \\
\text { artery, about } 8 \mathrm{~h}\end{array}$ \\
\hline 3 & M & 1950 & 1994 & $\begin{array}{l}\text { Dissecting aortic aneurysm Type } 1 \\
\text { (Marfan) preoperative neurology normal }\end{array}$ & $\begin{array}{l}\text { Aortic cross-clamping above left sub- } \\
\text { clavian artery, ligation of } 20 \text { intercostal- } \\
\text { lumbar arteries }\end{array}$ \\
\hline 4 & $\mathrm{M}$ & 1916 & 1968 & $\begin{array}{l}\text { Aortic coarctation preoperative neurology } \\
\text { normal }\end{array}$ & Unavailable \\
\hline 5 & M & 1957 & 1981 & $\begin{array}{l}\text { Traumatic laceration of the aortic arch } \\
\text { preoperative neurology normal }\end{array}$ & $\begin{array}{l}\text { Aortic cross-clamping above left sub- } \\
\text { clavian artery, ligation of four intercostal, } \\
\text { one mediastinal arteries }\end{array}$ \\
\hline 6 & M & 1981 & 1982 & $\begin{array}{l}\text { Aortic coarctation preoperative neurology } \\
\text { normal }\end{array}$ & $\begin{array}{l}\text { Aortic cross-clamping above left sub- } \\
\text { clavian artery, reimplantation of left sub- } \\
\text { clavian artery, ligation of two intercostal, } \\
\text { one mediastinal arteries }\end{array}$ \\
\hline 7 & M & 1938 & 1981 & $\begin{array}{l}\text { Dissecting aortic aneurysm Type III } \\
\text { (Marfan) preoperative neurology normal }\end{array}$ & $\begin{array}{l}\text { Aortic cross-clamping above left sub- } \\
\text { clavian artery, ligation of five intercostal } \\
\text { arteries }\end{array}$ \\
\hline 8 & $\mathrm{~F}$ & 1914 & 1987 & $\begin{array}{l}\text { Dissecting aortic aneurysm Type III } \\
\text { preoperative neurology normal }\end{array}$ & $\begin{array}{l}\text { Aortic cross-clamping above left sub- } \\
\text { clavian artery, ligation of } 20 \text { intercostal } \\
\text { arteries }\end{array}$ \\
\hline 9 & $\mathrm{M}$ & 1932 & 1990 & $\begin{array}{l}\text { Dissecting aortic aneurysm Type III } \\
\text { preoperative neurology normal }\end{array}$ & $\begin{array}{l}\text { Aortic cross-clamping below left sub- } \\
\text { clavian artery, } 90 \mathrm{~min} \text {, ligation of all } \\
\text { intercostals, except } 12 \text { th pair }\end{array}$ \\
\hline 10 & M & 1961 & 1978 & $\begin{array}{l}\text { Traumatic laceration of the aortic arch, } \\
\text { with preoperative paraplegia Frankel A }\end{array}$ & Suture of the lesion \\
\hline 11 & M & 1938 & 1995 & $\begin{array}{l}\text { Dissecting aortic aneurysm (sub renal) } \\
\text { preoperative intermittent claudication }\end{array}$ & Aortic cross-clamping below renal arteries \\
\hline 12 & M & 1945 & 1996 & $\begin{array}{l}\text { Dissecting aortic aneurysm Type IV } \\
\text { preoperative neurology normal }\end{array}$ & $\begin{array}{l}\text { Aortic cross-clamping above celiac trunk, } 55 \\
\text { min, reimplantation of celiac trunk, upper } \\
\text { mesenteric and two renal arteries }\end{array}$ \\
\hline
\end{tabular}


Table 2 Neurological status, ASIA Scores, Frankel Grade on initial and terminal examinations

\begin{tabular}{|c|c|c|c|c|c|c|c|c|c|c|c|c|}
\hline \multirow[b]{2}{*}{ No. } & \multirow[b]{2}{*}{ Level } & \multicolumn{4}{|c|}{ Initial Examination } & \multirow[b]{2}{*}{$D T R s$} & \multicolumn{6}{|c|}{ Follow-up examination } \\
\hline & & $\begin{array}{c}\text { Asia } M \\
\text { Score }\end{array}$ & $\begin{array}{c}\text { Asia PP } \\
\text { Score }\end{array}$ & $\begin{array}{c}\text { Asia LT } \\
\text { Score }\end{array}$ & $\begin{array}{c}\text { Frankel } \\
\text { Grade }\end{array}$ & & $\begin{array}{l}\text { Bladder } \\
\text { Function }\end{array}$ & $\begin{array}{l}\text { Extension } \\
\text { of Lesion }\end{array}$ & $\begin{array}{l}\text { Asia M } \\
\text { Score }\end{array}$ & $\begin{array}{c}\text { Asia PP } \\
\text { Score }\end{array}$ & $\begin{array}{c}\text { Asia LT } \\
\text { Score }\end{array}$ & $\begin{array}{c}\text { Frankel } \\
\text { Grade }\end{array}$ \\
\hline 1 & $\mathrm{~T} 10$ & 50 & 68 & 68 & A & Absent & Acontractile & $\mathrm{T} 11-\mathrm{S} 5$ & 50 & 68 & 68 & A \\
\hline 2 & $\mathrm{~T} 10$ & 50 & 68 & 68 & A & Absent & Acontractile & $\mathrm{T} 11-\mathrm{S} 5$ & 50 & 68 & 68 & A \\
\hline 3 & $\mathrm{~T} 4$ & 58 & 54 & 112 & $\mathrm{C}$ & Present & Dysynergia & T5-L3 & 60 & 59 & 112 & $\mathrm{C}$ \\
\hline 4 & C6 & 94 & 89 & 112 & $\mathrm{D}$ & $\begin{array}{c}\text { Present } \\
\text { Absent in } \\
\text { C7-C8 }\end{array}$ & Normal & $\mathrm{C} 7-\mathrm{T} 3$ & 94 & 89 & 112 & $\mathrm{D}$ \\
\hline 5 & L1 & 81 & 112 & 112 & $\mathrm{C}$ & Present & Normal & $\mathrm{L} 2-\mathrm{S} 1$ & 97 & 112 & 112 & $\mathrm{E}$ \\
\hline 6 & L1 & 52 & $*$ & $*$ & B & Absent & Normal & $\mathrm{L} 2-\mathrm{S} 2$ & 61 & 92 & 112 & B \\
\hline 7 & $\mathrm{~T} 10$ & 50 & 80 & 112 & $\mathrm{C}$ & Absent & Normal & $\mathrm{T} 11-\mathrm{S} 1$ & 58 & 80 & 112 & $\mathrm{C}$ \\
\hline 8 & $\mathrm{~T} 8$ & 77 & 80 & 112 & $\mathrm{D}$ & Absent & Acontractile & T9-S3 & 94 & 80 & 112 & $\mathrm{E}$ \\
\hline 9 & $\mathrm{~T} 10$ & 54 & 80 & 112 & $\mathrm{C}$ & Absent & Normal & $\mathrm{T} 11-\mathrm{S} 1$ & 73 & 94 & 112 & $\mathrm{C}$ \\
\hline 10 & T9 & ** & ** & ** & $\mathrm{C}$ & Absent & Normal & $\mathrm{T} 10-\mathrm{S} 2$ & ** & ** & ** & $\mathrm{C}$ \\
\hline 11 & L1 & 90 & 108 & 112 & $\mathrm{D}$ & Absent & Normal & L2 - L5 & 97 & 108 & 112 & $\mathrm{E}$ \\
\hline 12 & T7 & 57 & 56 & 88 & $\mathrm{C}$ & Absent & Acontractile & T8-S5 & 69 & 56 & 88 & $\mathrm{C}$ \\
\hline
\end{tabular}

Asia M Score: ASIA Motor Score, Asia PP Score: ASIA Pin Prick Score, Asia LT Score: ASIA Light Touch Score, DTRs: Deep Tendon Reflexes in lower limbs. *ASIA Score could not be performed in a 1 year old boy. **ASIA Score could not be performed because of an associated right brachial plexus lesion. ***Follow-up examination from $1-26$ years (average 7 years)

partial involvement of the spinal cord with an incomplete, more proximal than distal lesion, and often with asymmetrical motor impairment of the lower limbs. The level of the spinal cord lesion was thoracic in eight cases, lumbar in three and cervical in one. Three remarkable features could be found. Firstly, the absence of deep tendon reflexes with acontractility of the bladder suggest a lesional syndrome that extended over a variable number of spinal cord segments as in cases 1, 2, 8 and 12 . Secondly, normal bladder function, as in cases 4, 6, 7, 9, 10, 11 strongly suggesting sparing of both upper and lower motorneurone control with sparing of the white and grey matter at vesical level. Thirdly, the plurisegmental loss of temperature and pinprick sensation with sparing of touch and position sensations, as usually happens in syringomyelia, confirming the integrity of the posterior columns. This suggests an impairment of the sensory pathways through the grey matter of the spinal cord and not an impairment of the spino-thalamic tracts. In case 3 , the brisk tendon reflexes, intermittent spasms of the lower limbs and detrusor sphincter dyssynergia as well as sensory sparing, suggests an incomplete upper motorneuron lesion. This features in case 4, (Brown-Sequard configuration, absence of cervical deep tendon reflexes in $\mathrm{C} 7$ and $\mathrm{C} 8$, present lower limbs reflexes and loss of pinprick sensation between $\mathrm{C} 7$ and $\mathrm{T} 3$ ) would also suggest an associated central cord lesion. This combination reflects the involvement of both the grey and white matters. The combination of normal sensation together with electromyographic (EMG) data of lower motorneurone impairment and only mild weakness of the muscles of the lower limbs (Frankel C), with preservation of deep tendon reflexes suggest that the lesion, in case 5, is mostly in the grey matter. This sparing of tendon reflexes suggests some damage to the inhibitory interneurones in the intermediare grey matter of the anterior horns and some preservation of some motorneurone in the grey matter. This therefore confirms that in the majority of patients ischaemia to the spinal cord following trauma or surgery of the aorta, the central grey matter is more affected than the white matter. Spinal cord angiography was normal in case 10 , with the artery of Adamkiewicz feeding from the left 11 thoracic intercostal artery and there was an another anterior feeder from T6. MRI in case 1 reveals an atrophy from $\mathrm{T} 10$ to the conus. In case 3 there was segmental atrophy from $\mathrm{T} 5$ to $\mathrm{L} 1$, while in case 11 there was a signal on the T2 sequence in the conus. The MRI was normal preoperatively in case 12 . In addition, followup demonstrated that the symptomatology did not significantly improve over time. The localisation and extension of the lesions in the grey matter are drawn on the Figure 1.

\section{Discussion}

The clinical characteristics of the patients in our series highlight the topography of the various lesions in ischaemia of the spinal cord. We confirm our previous observations in $1983^{5}$, that most of the patients had incomplete lesions and that there were many symptoms suggestive of lower motorneurone damage. The motor weakness, loss of deep tendon reflexes and, EMG signs of denervation, point toward a localised lesion of the anterior grey matter of the spinal cord. The characteristics of the sensory impairment, with preservation of touch and position sensation in some patients as well as the suspended topography, suggest that the lesion is in the intermediate grey matter rather than in the white matter of the spinal cord. Azzarelli and Roessmann ${ }^{6}$ also suggested that the frequent involvement of the 

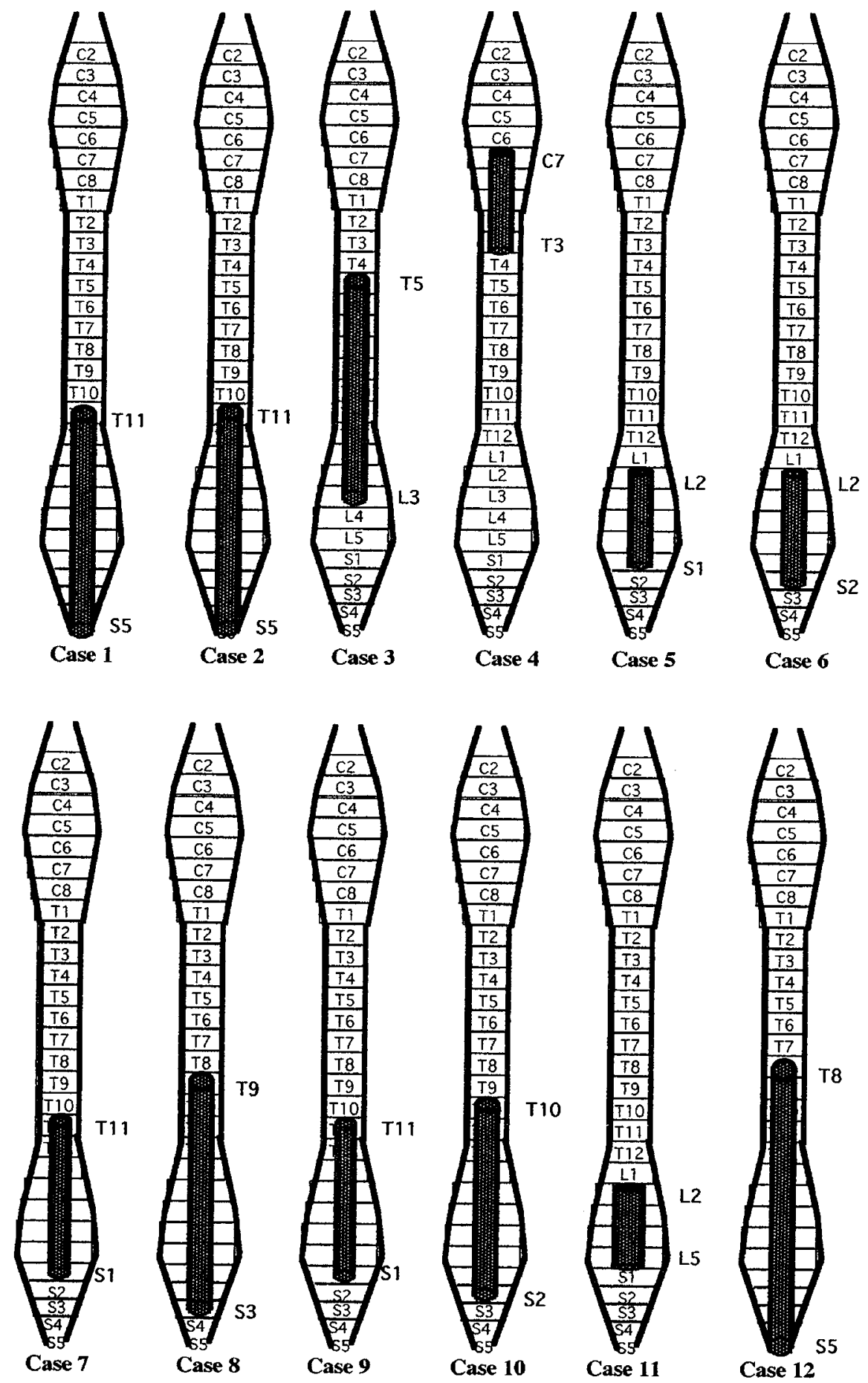

Figure 1 Localisation and extension of the lesions in the grey matter for each case

substantia gelatinosa which contains the second-order neurones in the pathways of temperature and pain, may explain the selective deficit for these sensory modalities; while the perservation of the white matter tracts could account for the preservation of touch and position senses. In nine of the 12 patients, the lesion and neurological impairment had remained incomplete and unsymmetrical without bowel and bladder dysfunction. The two patients with complete paraplegia remained flaccid with atonic bladders. These features, cannot be explained by impairment of the tracts in the white matter and/or an upper motornuerone lesion. They tend to point more towards impairment of the grey matter in the spinal cord. In 
a series of 29 patients, seen early in the course of their illness, Kewalramani et $a l^{7}$ indicated that most patients had an incomplete neurological impairment, with some preservation of sensation (74\%) and, a preservation of voluntary motor activity in the lower limbs in $55 \%$ of the patients. In addition deep tendon reflexes were brisk in five patients immediately after the onset of paralysis, hypoactive in four and absent in 20. On follow-up, three of his patients developed spasticity while 15 remained flaccid. It is also easy to explain the flaccidity in some patients with ischaemic lesion, but it is however more difficult to explain those patients who had brisk tendon reflexes or whose spasticity reappeared. Experimental and anatomical data enable us to propose an hypothesis to explain such a situation. Watson $^{8}$, documented clinically that the damage was confined to the anterior horn cells of lumbar and sacral segments of the spinal cord, with only partial involvement of the spinothalamic tracts carrying pain and temperature sensation, and sparing of posterior column sensations, as well as satisfactory bladder control. Kim et al ${ }^{9}$ reported, in 1988, anatomical data on three of 25 cases. They showed 'cavitary necrosis within the grey matter, as well as newly formed vascular channels and lipid-laden macrophages together with scattered hypertrophied astrocytes at the margins of the lesion' in these three post-mortem specimens. In only one of the three post-mortems, they found an extensive damage within both white and grey matter distally from the main central lesion. Since all of our patients are still alive, we are unable to verify our clinical data with regard to actual pathology of the grey and white matter. Crawford et $a l^{4}$ showed with MRI scanning, 10 days after the onset of the deficit, involvement of the grey matter. These findings were noted in those patients who had more profound deficits and were associated with a poor prognosis for significant recovery. In 1990 Mawad et al ${ }^{10}$ demonstrated by MRI studies, in 24 patients who underwent surgery for thoracoabdominal aortic aneurysms the sequela of cord ischaemia. They demonstrated the signal of 'owl's eyes' appearance in the anterior horns of the grey matter with mild ischaemia. With increasing severity of ischaemia they demonstrated the spread of the signal to involve the posterior horns of the grey matter which extended laterally to the white matter in severe ischaemia. In very severe cases, the whole cross section of the spinal cord was infarcted. The clinical symptoms and signs that we have demonstrated in our patients are almost specific for ischaemia of the spinal cord and the metabolic results. They are rarely seen in other pathologies. Laboratory data help to confirm the vulnerability of the grey matter to ischaemic conditions. Fried and Apparicio ${ }^{11}$, ligated the anterior spinal artery at various levels in 17 rhesus monkeys. Only nine monkeys became paraplegic. The post-mortem examination of the monkeys who were not paralysed, revealed that in four of the eight monkeys there were small areas of cellular destruction in the grey matter, particularly at the base of the anterior horns. Van
Harreveld and Khattab $^{12}$ and Schneider and Dralle ${ }^{13}$ have shown early sensitivity to ischaemia of the interneurones in layer VIII. Azzarelli and Roessmann $^{6}$ and Gilles and $\mathrm{Nag}^{14}$ found a neural loss at the base of the anterior horns in the spinal cords of patients who died after hypovolemia or hypoxia. In experimental ischaemia, some authors describe the advent of transient hypertonic symptoms. During selective spinal cord angiography in humans, Djindjian et $a l^{15}$ observed spasms in the lower limbs of some patients which disappear at the end of the procedure. In 1989 Mathé et al ${ }^{16}$ reported four angiographically documented cases of particular ischaemia of the spinal cord with permanent or transient clinical signs related to impairment of the anterior horns. He discussed in one case specific involvement of interneurones of the base of the anterior horns. This may explain why tendon reflexes can remain as in case 5. The anterior spinal artery syndrome, first described in 1908 by Preobrachenski ${ }^{17}$ and in 1909 by Spiller ${ }^{18}$, can also manifest itself with a smaller neurological lesion still in the territory of the anterior spinal artery. In these cases the central grey matter is more involved than the white matter. In such cases, although some degree of recovery could be observed, in general the improvement remains poor.

Regarding the pathophysiology of the lesions, the problem can be seen from three points of view, that of anatomical features, of blood flow of the spinal cord, and of postischaemic events in the neurones. A great deal is known about the anatomical features of the arterial blood supply of the spinal cord. There is a ventral spinal artery which runs anteriorly along the spinal cord. This ventral axis has some special characteristics. There are only two or three ventral radicular arteries, of which Adamkiewicz artery provides the major blood supply to the thoracolumbar segments of the cord. This ventral axis is not homogeneous and the flow forks in opposing directions between segments. This disposition allows a supply from the upper, as well as the lower segments. The feeder of the radicular arteries is variable from the intercostal or lumbar arteries and can only be identified in a patient by selective angiography. There are two thin posterior spinal arteries with a lower number of feeders. Kim et $a l^{9}$ suggested that in case of impairment of perfusion (hypovolemia or cross-clamping and according to the site of cross-clamping), preferential damage involved the grey matter and was associated with a flaccid, lower motoneurone type of weakness. They also suggested that localised damage, such as is seen following a lesion of a major radicular artery, may lead to localised spinal cord infarction in its territory of supply. Such an interpretation is acceptable except that, it does not take into account the role of the anastomotic inter-connections far away from the spinal cord, such as from the subclavian, intercostal or lumbar arteries, in the blood supply of the spinal cord. Angiographic data by Djindjian et $a l^{19}$ reveal 
that additional blood supply can come from the cervical trunks, vertebral and cervical arteries and, from the posterior lumbo-sacral radicular arteries which contribute to the anastomotic arch around the conus. It is therefore evident that blood flow can not only come from above downwards but also from below upwards. Furthermore anastomotic networks exist between intercostal arteries. Such an individual disposition serves to explain the differences in the impairment of the spinal cord after the cross-clamping of the aorta in different patients.

The normal spinal cord blood flow is maintained at between $55-60 \mathrm{ml} / \mathrm{min} / 100 \mathrm{~g}$. In laboratory conditions pathological and/or functional alterations occur if the blood flow is reduced to $15 \mathrm{ml} / \mathrm{min} / 100 \mathrm{~g}$. Some of these alterations can be incomplete and reversible. Hayashi et $a l^{20}$, with high-resolution hydrogen clearance measurements of the blood flow of the spinal cord in rats, reported that the local spinal cord blood flow maintains a $3: 1$ ratio between the grey and white matter. In addition Hayashi demonstrated both the higher vascular density and oxygen consumption with metabolic activity of the intermediate grey and lamina VIII in the ventral horn area. Griffiths ${ }^{21}$, Sasaki et $a l^{22}$ and Nemecek ${ }^{23}$ showed, from ultrastructural data that changes occur in the spinal grey matter on a centrifugal pathway depending on microvascularisation. Kobrine et $a l^{24}$, in a laboratory study, found that the sensory evoked potential did not disappear in the dorsal columns until the focal blood flow was zero. Sensory evoked potentials are therefore not effective in accurately monitoring the neural territory of the spinal anterior artery. In 1997 Kolenda et $a l^{25}$ studied both the microcirculatory (laser Dopler flowmeter) and segmental neurophysiological parameters (monosynaptic and polysynaptic reflexes) in cats, during spinal cord ischaemia after cross clamping of the aorta. $\mathrm{He}$ demonstrated that within the first two minutes of ischaemia there was an initial transient increase of reflexes (monosynaptic and polysynaptic) before they disappeared. He also demonstrated that the delay of the reflexes appearing was related to the depth of ischaemia. It may therefore be possible and beneficial from the observation of monosynaptic and polysynaptic reflexes during aortic surgery in humans. In aortic surgery two main conditions can cause a low blood flow: general hypotension which could occur spontaneously and with cross-clamping of the aorta. This could affect the microvasculature of the anterior artery. The second is through ligation of one or more anterior arteries supplying the ventral axis and causing widespread localised damage. These two factors can often be intertwined. Furthermore in 1995, Follis et $a l^{26}$ demonstrated a period of post ischemic hypoperfusion, lasting $6 \mathrm{~h}$ after a crossclamping of the aorta and left subclavian arteries for $11 \mathrm{~min}$ in the rat model, in the white and grey matter of thoracic and lumbar segments. In 1997 Sakurai et $a l^{27}$ found out selective motorneurone death and heat shock protein induction after spinal cord ischaemia in rabbits.

The ischaemia of the spinal cord alters the properties of the spinal neurones. Some neurones remain with a potential of recovery, some die. We know that some of these events occur with a decreasing blood flow. The depletion of the adenosine triphosphate produces a failure of the calcium membranes pumps, an increase of intracellular calcium and a release of the cytoplasmic enzymes. The damaged structural proteins induce the production of free radicals and neurotoxic amino acids, aspartate and glutamate. These free radicals cause a loss of membrane integrity, increase the ratio of vasoactive prostaglandins and produce further vasospasms and microvascular thrombosis. Such demonstrations permit better understanding of the ischaemic phenomena and delayed postischaemic spinal cord hypoperfusion after aortic cross-clamping. They lead us to consider, in future, that specific drugs could be suitable to reduce or prevent the neural lesions.

The risk of paraplegia during aortic surgery is known to depend on several factors. Regarding surgical procedures, Richard et $a l^{28}$ and Krieger and Spencer ${ }^{29}$ emphasized on: the site and nature of the lesion of the aorta, the clamping time (18-30 $\mathrm{min})$, the localisation (above left subclavian artery) of crossclamping, hypotension, the need for ligation of intercostal arteries and/or the artery of Adamkiewicz, the presence of collateral circulation, the factors of revascularisation by reimplantation, the preoperative diagnosis of paraplegia and the age of the patient above 65 years old. On another hand, Gharagozloo et $a l^{30}$ considers that the neural lesion depends on four main factors: decrease in spinal cord blood flow, rate of neuronal metabolism, post ischaemia reperfusion injury and post perfusion blood flow. Some particular measures have to be emphazised to allow: the best conditions for blood flow, depending on the localisation and duration of the cross-clamping ${ }^{29}$, by a shunt or a pulsatile bypass ${ }^{2}$, by CSF drainage ${ }^{4}$ and local injection of papaverine; the protection of regional arteries by the preoperative localisation ${ }^{28,31}$ and preoperative reimplantation; the monitoring of function of spinal pathways by somatosensory potentials, and electrospinogram, as proposed Stulmeier et $a l^{32}$, or better, by the monitoring of spinal reflexes; a chemical protection ${ }^{3,30}$ by superoxyde-dismutase, calcium-channels blockers, NMDA-receptors antagonists, barbiturates, steroids, naloxone and other agents, represents only an approach to reduce the lesions.

Paraplegia following experimental thoracic aortic occlusion was first observed in 1910 by a French physiologist, Carrel $^{33}$. It remains a devastating complication after the repair of an aneurysm or trauma of the aorta. We demonstrated in humans that in most cases the clinical signs were in favour of an incomplete lesion of the spinal cord, always with involvement of the grey matter, and that most patients 
did not improve. Some methods tend to decrease the incidence of such a complication, none of them with total success. The rehabilitation team has to keep a close collaboration with the vascular surgeon to provide, as soon as possible, the mangement of such patients. These observations allow a better understanding of ischaemia of the spinal cord. A great deal remains to be done to improve our knowledge of the mechanisms of the lesions, as well as their prevention and treatment.

\section{References}

1 Doppman J. Paraplegia after surgery for thoracoabdominal aneurysms: Russian roulette for the vascular surgeon. Radiology 1993; 189: $27-28$

2 Scheppens M, Defauw Jo, Hamerlijnck R, Vermeulen F. Utilisation d'un shunt pulsé gauche au cours du traitement chirurgical des anévrysmes de l'aorte thoraco-abdominale. Ann Chir Vasc 1995; 4: 327-338.

3 Cox G et al. Thoracoabdominal aneurysm repair: A representative experience. J Vasc Surg 1992; 5: 780-788.

4 Crawford ES et al. A prospective randomized study of cerebrospinal fluid drainage to prevent paraplegia after highrisk surgery on the thoracoabdominal aorta. J Vasc Sug 1991; 1: $36-46$.

5 Labat JJ et al. Complications médullaires de la chirurgie et des traumatismes aortiques. A propos de 7 observations. Ann Réadaptation Méd Phys 1983; 26: $193-201$.

6 Azzarelli B, Roessmann Q. Diffuse anoxic myelopathy. Neurology 1977; 11: $1049-1052$.

7 Kewalramani LS, Orth MS, Katta SR. Atraumatic Ischaemic Myelopathy. Paraplegia 1981; 19: 352-362.

8 Watson N. Paraplegia following cardiovascular surgery. Paraplegia 1979; 17: 294-297.

9 Kim W, Kim RC, Choi BH, Gordon SK. Non-traumatic ischaemic myelopathy: a review of 25 cases. Paraplegia 1988; 26: $262-272$.

10 Mawad ME et al. Spinal cord ischaemia after resection of thoracoabdominal aortic aneurysms: MR findings in 24 patients. AJR 1990; 155: $1303-1308$.

11 Fried LL, Apparicio O. Histologic studies after anterior spinal cord artery occlusion. Neurology 1973; 23: 289-294.

12 Van Harreveld A, Khattab FI. Electron microscopy of axphyxiated spinal cords of cats. J. Neuropathol Experiment Neurol 1967; 4: 522.

13 Schneider H, Dralle J. Ultra structural changes in the rat spinal cord after temporary occlusion of the thoracic aorta. Acta Neuropat 1973; 26: $301-315$.

14 Gilles FH, Nag D. Vulnerability of human spinal cord in transient cardiac arrest. Neurology 1971; 21: 833-839.

15 Djindjian R, Mamo H, Saimot G, Houdart R. Contractures tétaniformes paroxystiques des membres inférieurs au cours de l'artériographie sélective de l'artère d'Adamkiewicz. Rev Neurol 1968; 1: $178-184$

16 Mathé JF et al. Ischémie de la corne antérieure de la moelle. Rev Neurol 1989; 1: 60-64.

17 Preobraschenski PA. Ein Beitrag zur Lehre von der akuten syphilitischen Poliomyellitis. Neurol. Centr 1908; 29: 1069.
18 Spiller WG. Thrombosis of the cervical anterior median spinal artery; syphilitic acute anterior poliomyelits. J. Nerv \& Ment Dis 1909; 36: $601-603$.

19 Djindjian R, Hurth M, Houdart R. Artériographie et ischémie médullaire dorso-lombaire d'origine athéromateuse. (A propos de 5 cas). Rev Neurol 1970; 1: 5-14.

20 Hayashi N, Green BA, Vera R. Local spinal blood flow and oxygen metabolism. In: RA Davidoff (ed) Handbook of the Spinal Cord vol 2-3 Marcel Dekker Inc: New York 1984, pp 817-827.

21 Griffiths IR. Ultrastuctural changes in spinal gray matter microvasculature after impact injury. In: Cervos-Navarro J, Betz E, Ebhardt G, Ferszt R, Wüllenweber R (eds). Pathology of Cerebrospinal Microcirculation, Advances in Neurology vol 20. Raven Press: New York 1978, pp 415-422.

22 Sasaki S, Schneider H, Renz S. Microcirculatory disturbances during the early phase following experimental spinal cord trauma in the rat. In: Cervos-Navarro J, Betz E, Ebhardt G, Ferszt R, Wüllenweber R (eds). Pathology of Cerebrospinal Microcirculation, Advances in Neurology vol. 20. Raven Press: New York 1978, pp $423-431$.

23 Nemecek St. Morphological evidence of microcirculatory disturbances in experimental spinal cord trauma. In: CervosNavarro J, Betz E, Ebhardt G, Ferszt R, Wüllenweber R (eds) Pathology of Cerebrospinal Microcirculation, Advances in Neurology vol. 20. Raven Press: New York 1978, pp 395-405.

24 Kobrine AI, Evans DE, Rizzoli HG. Correlation of spinal cord blood flow, sensory evoked response, and spinal cord function in subacute experimental spinal cord compression. In: CervosNavarro J, Betz E, Ebhardt G, Ferszt R, Wüllenweber R (eds). Pathology of Cerebrospinal Microcirculation, Advances in Neurology vol. 20. Raven Press: New York 1978, pp 389-394.

25 Kolenda $\mathrm{H}$ et al. Influence of short-term ischemia on segmental spinal cord reflex function in cats. J Spinal Disord 1997; 1: $68-78$.

26 Follis $\mathrm{F}$ et al. Experimental delayed postischemic spinal cord hypoperfusion after aortic cross-clamping. Can J Neurol Sci 1995; 22: $202-207$.

27 Sakurai $\mathrm{M}$ et al. Selective motor neuron death and heat shock protein induction after spinal cord ischemia in rabbits. $J$ Thorac Cardiovasc Surg 1997; 113: 160-164.

28 Richard I, Guilmet D, Bical O, Diaz F, Bachet J, Goudot B, Dubois C, Brodaty D. La protection médullaire au cours de la chirurgie de l'aorte thoracique et thoraco-abdominale. In: Kieffer E (ed) Chirurgie de l'aorte Thoracique Descendante et ThoracoAbdominale. Expansion Scientifique Française: Paris 1986, pp: $104-110$.

29 Krieger KH, Spencer FC. Is paraplegia after repair of coarctation of the aorta due principally to distal hypotension during aortic cross-clamping? Surgery 1985; 97: 2 - 7 .

30 Gharagozloo $\mathrm{F}$ et al. Spinal protection during surgical procedures on the descending thoracic and thoracoabdominal aorta. Review of current techniques Chest 1996; 109: 799-809.

31 Bizouarn P, Sellier E, Pinaud M. Réanimation périopératoire pour la rupture de l'anévrysme de l'aorte thoracoabdominale. In: Principes de Réanimation Chirurgicale. Arnett and Blackwell 1995, pp 959-966.

32 Stulmeier KD et al. Use of the electrospinogram for predicting harmful spinal cord ischemia during repair of thoracic or thoracoabdominal aortic aneurysms. Anesthesiology 1993; 79: $1170-1176$.

33 Carrel A. Report on the experimental surgery of the thoracic aorta and heart. Ann Surg 1910; 52: 83 